\title{
Impairment of monocyte "lectin-like" receptor activity in Type 1 (insulin-dependent) diabetic patients
}

\author{
E.J.Glass ${ }^{1}$, J.Stewart ${ }^{1}$, D. M. Matthews ${ }^{2}$, A.Collier ${ }^{2}$, B. F.Clarke ${ }^{2}$ and D. M. Weir ${ }^{1}$ \\ ${ }^{1}$ Department of Bacteriology, University Medical School and ${ }^{2}$ Diabetic Department, Royal Infirmary, Edinburgh, Scotland
}

Summary. In order to investigate whether the ability of peripheral blood monocytes to bind bacteria is impaired in diabetes, we studied carbohydrate-binding ("lectin-like") receptors and the receptor for the Fc portion of immunoglobulin on monocytes from 25 male Type 1 (insulin-dependent) diabetic patients and 10 age-matched healthy control subjects. Peripheral blood monocytes from the diabetic patients expressed lower levels of "lectin-like" receptors compared to the control subjects, whereas the expression of the receptor for the $\mathrm{Fc}$ portion of immunoglobulin was similar in both populations. There was no correlation between the degree of "lectin-like" binding activity and plasma glucose concentration or glycaemic control. Recognition of unopsonized bacteria by the "lectin-like" receptor is impaired in Type 1 diabetes; this may affect the efficient elimination of potential pathogens.

Key words: Diabetes, monocytes, "lectin-like" receptors, bacterial recognition.
The mechanisms responsible for the immune dysfunction and increased susceptibility to infection [1,2] seen in patients with diabetes mellitus are not yet understood. Studies with alloxan-induced diabetes in mice suggest that macrophage cell-surface receptors and function are altered in the diabetic state [3]. These cells perform critical and diverse functions in the induction, regulation and amplification of the immune response [4]. Their activity is controlled by recognition events at the cell surface. Identified receptor sites on macrophage cell membranes include receptors for the $\mathrm{Fc}$ portion of immunoglobulin (Fc), complement components, carbohydrates and various lymphokines. The alteration in the expression of these cell surface molecules may drastically affect cellular activity and function.

A carbohydrate binding receptor that recognises various bacterial species by their cell wall sugars has been described [5]. This "lectin-like" receptor is blocked by simple sugars such as D-glucose and D-galactose [6], and is associated with the major histocompatibility antigens that are involved in the inductive phase of the immune response [7].

In this study we report on the expression of "lectinlike" and Fc receptors on monocytes from Type 1 diabetic patients, and relate this to the level of plasma glucose, fructosamine and glycosylated haemoglobin.

\section{Materials and methods}

\section{Preparations of monocyte monolayers}

Peripheral blood was obtained from 25 male Type 1 diabetic patients, age $30.2 \pm 1.0$ years (mean $\pm S E M$ ), mean duration of diabetes $10.8 \pm 1.5$ years, and from 10 non-diabetic male volunteers, age $27.6 \pm 1.5$ years. The diabetic patients received no medication other than insulin, and had no other underlying illnesses, particularly infections. Mononuclear cells were purified on Ficoll/Hypaque (density $1.077 \mathrm{~g} / \mathrm{ml}$ ) by the method of Boyum [8], and were resuspended in Eagle's minimum essential medium without serum to give a final concentration of $2 \times 10^{5}$ monocytes $/ \mathrm{ml}$. One millilitre of the cell suspension was layered onto $13 \mathrm{~mm}$ diameter (no.1) glass coverslips in tissue culture plate wells and incubated at $37^{\circ} \mathrm{C}$ for $1 \mathrm{~h}$. Non-adherent cells were removed by washing with Dulbecco's phosphate buffered saline (D.PBS).

\section{Detection of "lectin-like" receptors}

Staphylococcus epidermidis obtained from the departmental teaching collection was grown in nutrient broth (Oxide no. 2, Oxide Ltd, Basingstoke, Hampshire, UK), harvested in log phase and killed by $24 \mathrm{~h}$ exposure to $0.5 \%$ formalin at $4{ }^{\circ} \mathrm{C}$. The organisms were washed with $0.15 \mathrm{~mol} / 1 \mathrm{NaCl}$ to remove the formalin and stored at $4{ }^{\circ} \mathrm{C}$ for no longer than 3 weeks.

The monocyte monolayers were overlaid with $1 \mathrm{ml}$ of the bacteria in D.PBS containing $\mathrm{Ca}^{++}$and $\mathrm{Mg}^{++}$ions $(0.9 \mathrm{mmol} / \mathrm{l}$ and $0.4 \mathrm{mmol} / 1 \mathrm{respectively)}$ and incubated for $1 \mathrm{~h}$ at $37^{\circ} \mathrm{C}$. Non-attached organisms were removed by repeated washing with D.PBS. Coverslips were air dried, fixed in methanol and stained with May Grunwald/Giemsa. "Lectin-like" receptor expression was estimated 


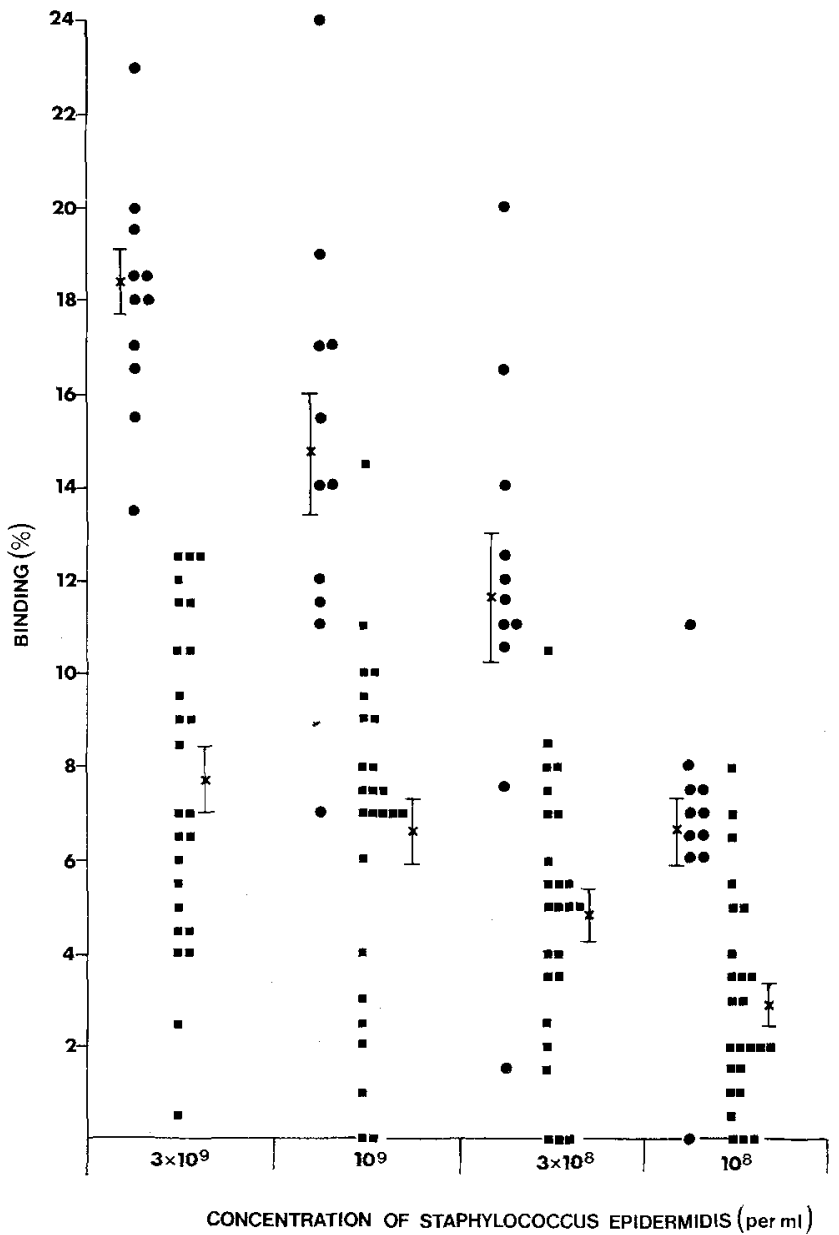

Fig. 1. The percentage monocyte binding Staphylococcus epidermidis in control subjects (O) and Type 1 diabetic patients ( $\mathbf{a})$. Bars represent the mean $\pm 1 \mathrm{SEM}$

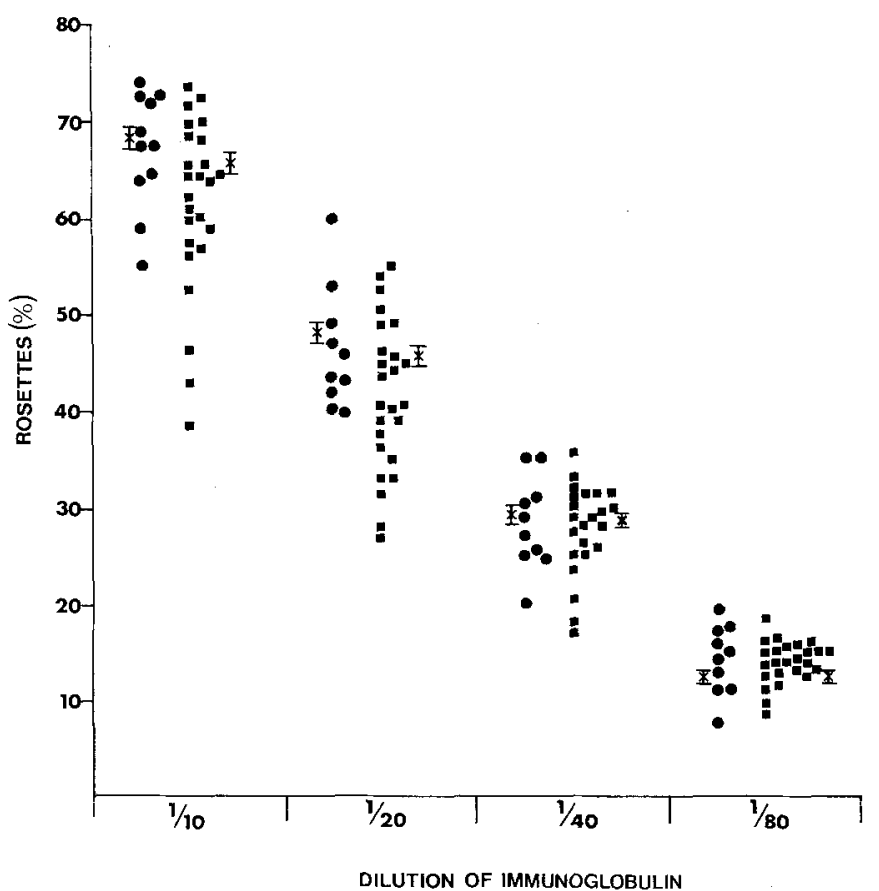

Fig. 2. The percentage monocyte rosettes with $\operatorname{lgG} 2 b$ coated sheep erythrocytes in control subjects (O) and Type 1 diabetic patients (覀). Bars represent the mean \pm 1 SEM
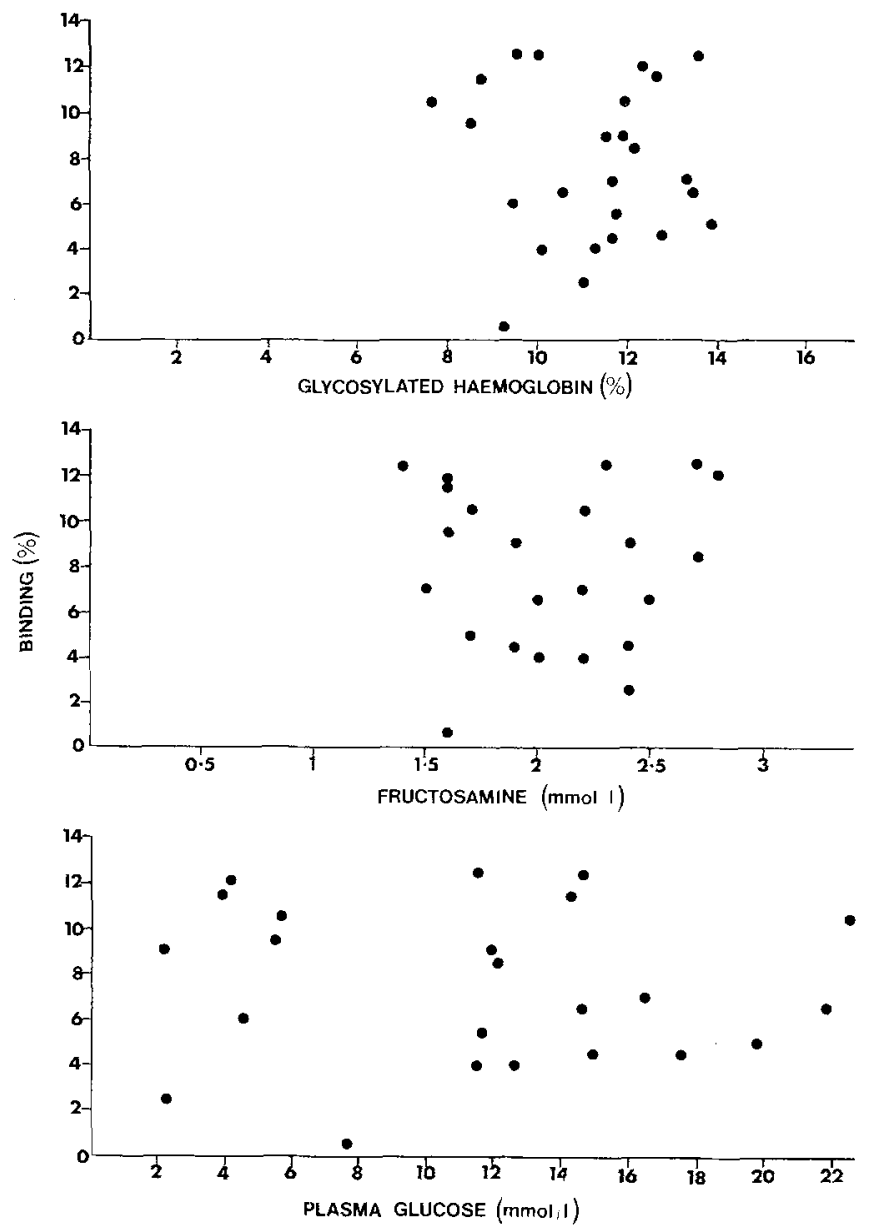

Fig.3. Comparison of the binding of Staphylococcus epidermidis (at $3 \times 10^{9}$ organisms $/ \mathrm{ml}$, to monocytes with the level of glycosylated haemoglobin $\left(\mathrm{HbA}_{1}\right)$, fructosamine and plasma glucose

by counting the monocytes with bacteria attached at two or more discrete points. Duplicate coverslips were used and on each 200 monocytes were examined. The results are expressed as the percentage of cells binding bacteria.

\section{Detection of Fc receptors}

Sheep erythrocytes coated with immunoglobulin $\left(\mathbf{E A}_{G}\right)$ were prepared by incubating equal volumes of mouse monoclonal anti-sheep erythrocytes antibody (IgG2b MAS 13c Sera-Lab Ltd., Crawley Down, Sussex, UK) diluted in Hanks' balanced salt solution (BSS) and sheep erythrocytes $\left(10^{9} / \mathrm{ml}\right)$ for $30 \mathrm{~min}$ at $37^{\circ} \mathrm{C}$. The sensitized sheep erythrocytes were washed twice with Hanks' BSS and stored at $4{ }^{\circ} \mathrm{C}$ for no longer than 1 week.

Two millilitres of $\mathrm{EA}_{\mathrm{G}}\left(2.5 \times 10^{7} / \mathrm{ml}\right)$ were added to each monolayer, centrifuged for $8 \mathrm{~min}$ at $50 \mathrm{~g}$ and incubated for $45 \mathrm{~min}$ at $20^{\circ} \mathrm{C}$. Non-adherent erythrocytes were removed by gentle washing with Hanks' BSS. The coverslips were then treated and counted as for "lectin-like" receptors.

\section{Measurement of plasma glucose, glycosylated haemoglobin and fructosamine}

Plasma glucose was measured using a standard glucose oxidase method. Total glycosylated haemoglobin was determined by an electrophoretic method [9] and serum fructosamine was measured by the method of Johnson et al. [10] adapted for use on the Cobas Fara cen- 
trifugal analyser (Roche Products Ltd., Welwyn Garden City, UK). Values for the normal control subjects were: glycosylated haemoglobin $5.7-8.2 \%$, fructosamine $1.1-1.6 \mathrm{mmol} / 1$ and plasma glucose $3.2-5.3 \mathrm{mmol} / 1$

\section{Statistical analysis}

The levels of "lectin-like" and Fc receptors on the monocytes from the Type 1 diabetic patients and control subjects were compared using Student's t-test, and correlations were analysed using linear leastsquares fit. A $p$ value of $<0.05$ was considered statistically significant.

\section{Results}

The percentage of monocytes from Type 1 diabetic patients and normal controls that bound unopsonised Staphylococcus epidermidis is shown in Figure 1. The level of detectable "lectin-like" receptors was significantly lower in the Type 1 diabetic patients at all doses of the bacterium $(p<0.001)$. In contrast, there was no difference in $\mathrm{Fc}$ receptor expression between the two groups (Fig.2). There was no difference between the percentage of monocytes in the ficoll/hypaque interface from the diabetic patients and the control subjects.

The percentage of "lectin-like" receptor positive monocytes, at the highest bacterial concentration used $\left(3 \times 10^{9} / \mathrm{ml}\right)$, did not correlate with the levels of plasma glucose, total glycosylated haemoglobin and serum fructosamine (Fig.3).

\section{Discussion}

The monocyte "lectin-like" receptor that recognises, binds and phagocytoses unopsonised bacteria may be important in the initiation of an immune response in a non-immune individual. This receptor is blocked in vitro by concentrations of D-glucose similar to those found in the plasma of hyperglycaemic patients [6]. Studies with alloxan-induced diabetic mice suggest that the diabetic environment affects the function of mononuclear phagocytes [3]. In the mouse model the binding activity of the "lectin-like" receptor is depressed; in addition, macrophages from diabetic mice are less efficient as accessory cells in antigen-dependent $T$ cell proliferation than normal macrophages. Thus, "lectin-like" receptor expression and activity can be modulated by exposure to elevated glucose concentrations.

The results of this study demonstrate that monocytes from insulin-dependent diabetic patients have a lower level of detectable "lectin-like" receptors than monocytes from normal non-diabetic individuals. The mechanisms for this depressed expression of the carbohydrate recognising receptor is not clear. There appears to be a specific effect on the "lectin-like" receptor, since there was no difference in $\mathrm{Fc}$ receptor expression between diabetic patients and normal control subjects (Fig. 2). The fact that greater than $70 \%$ of peripheral blood monocytes express detectable Fc receptors, whereas only about $20 \%$ bind Staphylococcus epidermidis, is consistent with the marked heterogeneity found in mononuclear phagocyte populations [11]. It seems unlikely that the lower levels of "lectin-like" receptor were the result of direct blocking of the receptors by the elevated blood glucose levels. The monocytes were exposed to prolonged incubations and washings in medium with physiological levels of glucose $(5 \mathrm{mmol} / \mathrm{l})$. The receptor on monocytes from both diabetic patients and control subjects can be inhibited to the same extent in vitro by glucose at a concentration of $20 \mathrm{mmol} / 1$ (J.Stewart, unpublished observation), suggesting that the binding seen in the diabetes was still mediated by the "lectin-like" receptor. In addition, there was no correlation between the plasma glucose level at the time of venepuncture and the level of "lectin-like" receptor expression (Fig. 3).

There was no evidence that the degree of prevailing glycaemic control over the previous few weeks, as assessed by total glycosylated haemoglobin and fructosamine, had any additional effect on the expression of "lectin-like" receptors (Fig. 3). The binding assay used in this study cannot distinguish between the possibility that the reduced binding in diabetes is due to a decrease in receptor number and/or affinity, or to a reduction in the proportion of monocytes expressing the receptor. Assays are being developed to investigate this point. It is possible that once the monocytes have been exposed to a hyperglycaemic environment their "lectin-like" receptor activity is impaired to its maximal extent. Prolonged exposure to high concentrations of glucose could modulate the activity or expression of the "lectin-like" receptor. As has been proposed for other membrane components [12], high blood glucose concentration may lead to non-enzymatic glycosylation of the receptor, altering its activity. Alternatively, continuous interactions of glycosylated serum proteins with the receptor may disturb its normal cellular distribution and turnover. Although one patient had a total glycosylated haemoglobin level within the normal range, he still had lower bacterial binding levels than the control subjects.

Thus, insulin-dependent diabetic patients have lower levels of "lectin-like" receptors on their monocytes, and this may have consequences for their ability to mount as effective an immune response as non-diabetic persons. Even a brief delay in raising a specific defence, through the activities of macrophages, may be critical when challenge occurs. This may partially explain the increased susceptibility to infection characteristic of diabetic patients.

Acknowledgements. This work was supported by the British Diabetic Association through an Eli Lilly Fellowship to E.J.Glass. 


\section{References}

1. Gordon OP (1983) Morbidity and mortality from diabetes mellitus. A look at preventable aspects. Am J Pub Health 73: 1156-1158

2. Bagdade JD (1976) Phagocytic and microbicidal function in diabetes mellitus. Acta Endocrinol (Copenh) 83 [Suppl 205]: 27-33

3. Glass EJ, Stewart J, Weir DM (1986) Altered immune function in alloxan induced diabetes in mice. Clin Exp Immunol 65: 614-621

4. Unanue ER (1984) Antigen-presenting function of the macrophage. Ann Rev Immunol 2: 395-428

5. Ogmundsdottir HM, Weir DM (1976) The characteristics of binding of Corynebacterium parvum to glass-adherent mouse peritoneal exudate cells. Clin Exp Immunol 26: 334-339

6. Glass EJ, Stewart J, Weir DM (1981) Presence of bacterial binding "lectin-like" receptors on phagocytes. Immunology 44: $529-534$

7. Stewart J, Glass EJ, Weir DM (1982) Macrophage binding of Staphylococcus albus is blocked by anti I-region alloantibody. Nature 298: $852-853$

8. Boyum A (1968) Isolation of leukocytes from human blood. Further observations. Methyl cellulose, dextran and Ficoll as eryth- rocyte-aggregating agents. Scand J Clin Lab Invest 21 [Suppl 97]: $31-50$

9. Read A, Tibi L, Smith AF (1980) Assessment of a simple electrophoretic method for measuring HbAl. Clin Chim Acta 108: 487-491

10. Johnson RN, Metcalf PA, Baker JR (1982) Fructosamine: a new approach to the estimation of glycosyl protein. An index of diabetic control. Clin Chim Acta 127: 87-95

11. Dougherty GJ, McBride WH (1984) Macrophage heterogeneity. J Clin Lab Immunol 14: 1-11

12. Brownlee M, Vlassara H, Cerami A (1984) Non-enzymatic glycosylation and the pathogenesis of diabetic complications. Ann Intern Med 101: 527-537

Received: 24 October 1986

and in revised form: 12 February 1987

Dr. John Stewart

Department of Bacteriology

University of Edinburgh Medical School

Teviot Place

Edinburgh EH8 9AG

UK 